\title{
Increase in the irrigated area of sugarcane and its potential in the bioenergetic generation of Brazil
}

Job Teixeira de Oliveira ${ }^{1}$, Rubens Alves de Oliveira ${ }^{2}$, Oswaldo Arce Brito ${ }^{3}$, Fernando França da Cunha ${ }^{2}$, Ricardo Gava ${ }^{4}$

${ }^{1}$ Universidade Federal do Mato Grosso do Sul - UFMS, MS. ${ }^{2}$ Universidade Federal de Viçosa - UFV, MG. ${ }^{3}$ HidroEng. ${ }^{4}$ Universidade Federal do Mato Grosso do Sul - UFMS, MS. E-mail: job.oliveira@hotmail.com

\begin{abstract}
Sugarcane has a large capacity for producing electricity using completely clean technology from a renewable source, contributing to environmental preservation. This study aimed to evaluate the increase in biomass resulting from the implementation of irrigation in Brazilian sugarcane plantations, estimate the potential for cogeneration, and calculate how much it will be possible to increase the Brazilian energy cogenerated with sugarcane bagasse and the impact on the Brazilian energy matrix. The increase in irrigation in the rainfed areas of Brazilian sugarcane plantations has substantial potential in increasing biomass for energy cogeneration. Considering an increase of $15 \%$ in the sugarcane plantation yields in rainfed areas achieved by the increase in irrigation, it leads to a potential increase of 96.39 million tons of sugarcane and 26.80 million tons biomass produced. In the energy matrix, the potential impact is $1.42 \mathrm{GWh}$ of cogenerated energy, which corresponds to a $12.47 \%$ increase in cogeneration in the sugar-energy sector and a $0.85 \%$ increase in Brazil's energy matrix. The expansion of the sugarcane irrigated area contributes to the increase in the production of bagasse and bioenergetic generation in Brazil.
\end{abstract}

Keywords: sugarcane bagasse, biomass, cogeneration, renewable energy, carbon recovery.

\section{Aumento da área irrigada de cana-de-açúcar e seu potencial na geração bioenergética do Brasil}

\section{Resumo}

A cana-de-açúcar tem grande capacidade de produção de energia elétrica com tecnologia totalmente limpa, de fonte renovável, contribuindo com a preservação ambiental. O objetivo da presente pesquisa foi avaliar o incremento de biomassa advinda da implantação de irrigação nos canaviais brasileiros, estimar o potencial de cogeração, e calcular o quanto será possível aumentar a energia brasileira cogerada com bagaço de cana-de-açúcar e o impacto na matriz energética brasileira. O incremento de irrigação nas áreas de sequeiros dos canaviais brasileiros tem um potencial substancial no incremento de biomassa para a cogeração de energia. Considerando um aumento de $15 \%$ na produção dos canaviais das áreas de sequeiro, conquistados a partir do incremento de irrigação, ocasiona em um potencial de aumento de 96,39 milhões de toneladas de cana-de-açúcar e 26,80 milhões de toneladas de biomassa produzida. Na matriz energética, o impacto potencial é de $1,42 \mathrm{GWh}$ de energia cogerada que corresponde a $12,47 \%$ de aumento de cogeração no setor sucroenergético e $0,85 \%$ de aumento na matriz energética do Brasil. A expansão da área irrigada de cana-de-açúcar contribui com o aumento da produção de bagaço e geração bioenergética do Brasil.

Palavras chaves: bagaço de cana-de-açúcar, biomassa, cogeração, energia renovável, resgate carbono.

\section{Introduction}

Sugarcane has a large capacity for producing electric energy using totally clean technology from a renewable source, which contributes to environmental preservation. According to CONAB (2020), the final numbers for 
the $2019 / 2020$ harvest presented a harvested area of 8,481.2 thousand hectares of sugar cane destined for sugar and alcohol activity, a number $1.3 \%$ lower than in the past harvest. The yield for the $2019 / 20$ harvest was $75.78 \mathrm{t} \mathrm{ha}^{-1}$. These data give Brazil first place in the ranking of sugarcaneproducing countries.

According to the study carried out by ANA (2017), approximately 1.72 million hectares grown with sugarcane are irrigated, which corresponds to about $17 \%$ of the sugarcane grown in Brazil's south-central regions. From the total sugarcane irrigated, 1.69 million hectares $(98.4 \%)$ is for salvage; irrigation is usually applied once or twice during the year. The purpose of salvage irrigation is to guarantee the initial growth stand of plant cane and ratoon. Only 27.2 thousand hectares (1.58\% of the total irrigated) are fully irrigated or with a deficit. Full irrigation is understood as that which can supply all the crop's water needs throughout the year. Deficit irrigation is that practiced throughout the year but not with the total water required by the crop.

Oliveira et al. (2020) found good results with the installation of central pivot irrigation in sugarcane plantations in the Brazilian Cerrado region; they found yield increased by $66 \%$ concerning the yield of sugarcane areas planted under rainfed conditions in Brazil. It is worth noting that the increase in yield in the sugarcane plantations implies an increase in dry matter (bagasse) for the cogeneration of electric energy.

According to the Brazilian Sugarcane Industry Association (UNICA, 2018), in terms of annual evolution of installed capacity, biomass had its record in 2010, with 1,750 MW (equivalent to $12.5 \%$ of an Itaipu Plant), the result of investment decisions before 2008, when the scenario was stimulating the -energy sector's expansion. However, the biomass source, which already represented $32 \%$ of the annual growth of installed capacity in the country, participated in 2017 with $7 \%$ of the annual expansion of installed capacity in Brazil.

In the last decade, the debate in the international community on climate change and the need to reduce dependence on hydrocarbons has come to play a leading role, especially within the framework of the United Nations Framework Convention on Climate Change (UNFCCC) (FAZZI et al., 2020). After approval by the National Congress, Brazil pledged to reduce greenhouse gas emissions, by 2025 , by $37 \%$ below 2005 levels. By 2030, the reduction is expected to be
43\% below 2005 levels. To this end, the country has committed itself to increase the share of sustainable bioenergy in its energy matrix to approximately $18 \%$ by 2030 and achieving an estimated $45 \%$ share of renewable energy in the composition of the energy matrix in 2030.

Given the above, due to the advantages of using biomass, the increase in the yield of sugarcane plantations, and the agreement signed by Brazil in the Paris agreement, this study aims to assess the increase in biomass resulting from the implementation of irrigation in Brazilian sugarcane plantations, estimate the potential for cogeneration, and calculate how much it will be possible to increase the Brazilian energy cogenerated with sugarcane bagasse and the impact on the Brazilian energy matrix.

\section{Material and Methods}

The study area was the entire territory of Brazil. The database used was the one made available by the National Supply Company (CONAB, 2020) for the cultivation of sugarcane for the $2019 / 2020$ harvest. The data refer to the cultivation of sugarcane in the period between April 2019 and March 2020. Brazil is a country of great territorial extension $\left(8,516,000 \mathrm{~km}^{2}\right)$, and the production of sugarcane was obtained for different conditions of biomes (Amazon, Caatinga, Cerrado, Atlantic Forest, Pampa, and Pantanal) and climates (Equatorial, Tropical, Tropical Semi-arid, Tropical Altitude, Tropical Coastal, and Subtropical).

The rainfed sugarcane plantations produced 642.72 million tons in the 2019/2020 harvest, according to CONAB (2020), and the calculation of the increase in the amount of sugarcane produced (ASP) was done according to Equation 1. The increase in production of rainfed sugarcane, in percentage, refers to the additional sugarcane production that is recommended to be achieved when we add irrigation in the cane fields, as reported by OLIVEIRA et al. (2020).

$$
A S P=R S P+\% I P
$$

Where: $\mathrm{RSP}=$ rainfed sugarcane production (millions of tons) and \%IP = the percentage of increase in rainfed sugarcane production.

The fiber is the sugarcane's component material insoluble in water, composed of cellulose, hemicellulose, lignin, pentosans, pectins, proteins, and phenolic compounds, among others. According to the Secretariat of 
Industrial Technology (STI) and the Ministry of Industry and Commerce (MIC) cited by Tavares et al. (2014), one ton of sugarcane provides approximately $278 \mathrm{~kg}$ of bagasse with $50 \%$ moisture (about $140 \mathrm{~kg}$ of dry mass), and this is constituted (on a dry basis) by approximately $50 \%$ of cellulose, $28 \%$ hemicellulose, $20 \%$ lignin and $2 \%$ ash and other compounds (proteins, enzymes, and phenolic compounds). Thus, the amount of biomass produced was calculated using Equation 2:

$$
A B P=Q C P \quad 0.278
$$

Where: $A B P=$ amount of biomass produced (millions of tons), QCP = amount of sugarcane produced (millions of tons), and 0.278 is the constant regarding the biomass content in sugar cane.

The bioenergy obtained through sugarcane bagasse, corresponding to the rainfed area, was estimated using Equation 3:

$$
\text { BEAS }=\text { TEC }(\text { TCA TRA })
$$

Where: BERA is the bioenergy of the rainfed area (GWh), TEC is the total energy cogenerated in Brazil (GWh), TCA is the total area of sugarcane planted in Brazil (10.2 million hectares), and TRA is the total rainfed area, which is 8.48 million hectares, according to ANA (2017).

The following Equation estimated the energy corresponding to the irrigated area in Brazil (EIA):

$$
E I A=T E C(T C A T I A)
$$

Where: TIA is the total irrigated area of sugarcane in Brazil (1.72 million hectares).

In 2016, according to the Energy Research Company (EPE 2017), among the 378 sugar cane biomass plants in operation, $44 \%$ sold electricity, representing a slight increase over the previous year, which was $40 \%$. Thus, there are more than 200 sugar-energy plants, according to EPE, which, with existing biomass in the sugarcane plantations, can undergo a process of investment in the reform ("retrofit") of their units, besides the investments aimed at the use of bagasse, straw, and biogas from vinasse, and become major generators of bioelectricity for the network.

Tables 1, 2, and 3 show the values related to the quantities of energy produced in Brazil, by different sources, according to data provided by ANEEL (2018).

Table 1. Sources used in Brazil - Phase: Operation.

\begin{tabular}{lccc}
\hline \multicolumn{1}{c}{ Origin } & Quantity & Power Granted (kW) & $\%$ \\
\hline Fossil & 2452 & $28,433,989$ & 17.02 \\
Biomass & 557 & $14,754,682$ & 8.83 \\
Nuclear & 2 & $1,990,000$ & 1.19 \\
Water & 1325 & $107,612,782$ & 64.43 \\
Wind & 527 & $12,916,439$ & 7.73 \\
Solar & 2210 & $1,306,483$ & 0.78 \\
Undi-Electrical & 1 & 50 & 0.00 \\
\hline Total & 7074 & $167,014,424$ & 100 \\
\hline
\end{tabular}

Source: ANEEL, 2018.

Table 2. Detail of the sources of biomass used in Brazil.

\begin{tabular}{lccc}
\hline \multicolumn{1}{c}{ Biomass source } & Quantity & Power Granted (kW) & $\%$ \\
\hline Forest & 98 & $3,170,745$ & 21.49 \\
Urban solid waste & 21 & 140,335 & 0.95 \\
Animal waste & 14 & 4,481 & 0.03 \\
Liquid biofuels & 3 & 4,670 & 0.03 \\
Agroindustrials & 421 & $11,434,451$ & 77.5 \\
\hline Total & 557 & $14,754,682$ & 100 \\
\hline
\end{tabular}

Source: ANEEL, 2018. 
Table 3. Brazilian agribusinesses that generate renewable energy.

\begin{tabular}{lccc}
\hline \multicolumn{1}{c}{ Source of Agroindustries } & Quantity & Power Granted (kW) & $\%$ \\
\hline Sugarcane Bagasse & 405 & $11,356,470$ & 99.32 \\
Rice husk & 12 & 45,333 & 0.4 \\
Biogas-AGR & 2 & 948 & 0.01 \\
Elephant Grass & 2 & 31,7 & 0.28 \\
\hline Total & 421 & $11,434,451$ & 100 \\
\hline
\end{tabular}

Source: ANEEL, 2018.

Total energy cogenerated is:

$$
T E C=E R A+E I A
$$

Therefore, the increase in cogenerated energy in the sector (CES), in\%, is given by:

$$
\text { CES }=11,35647+\% I A
$$

Already the cogenerated energy in Brazil (CEB) is given by the representative increase in cogeneration resulting from the percentage of increase in rainfed sugarcane fields and is given by:

$$
C E B=\frac{T E C}{T E B} 100
$$

Where: TEB is the total energy of Brazil
The calculations were made in an Excel spreadsheet of the Microsoft Office package. The methodology used for the calculation assumed that the increase in sugar cane production is linked to the increase in irrigation; investment in technology implies a percentage increase in cogeneration. With a greater mass of sugarcane, an equal proportion of biomass for cogeneration of electric energy is increased.

\section{Results and Discussion}

In the present study, the increase in sugarcane yield ranged from 0 to $30 \%$ with the implantation or increase of irrigation in the sugarcane plantations. Table 4 presents the increase in the amount of cogenerated energy due to increased biomass production in rainfed areas resulting from increased irrigation. (GWh).

Table 4. Values concerning the increase in yield in rainfed sugarcane plantations, in percentage.

\begin{tabular}{lcccccccc}
\hline IAC & $\%$ & $\mathbf{0}$ & $\mathbf{5}$ & $\mathbf{1 0}$ & $\mathbf{1 5}$ & $\mathbf{2 0}$ & $\mathbf{2 5}$ & $\mathbf{3 0}$ \\
\hline PRS & million t & 642.61 & 674.75 & 706.88 & 739.01 & 771.14 & 803.27 & 835.40 \\
\hline QBP & million $t$ & 178.65 & 187.58 & 196.51 & 205.44 & 214.38 & 223.31 & 232.24 \\
\hline ERA & GWh & 9.44 & 9.91 & 10.39 & 10.86 & 11.33 & 11.80 & 12.27 \\
\hline EIA & GWh & 1.92 & 1.92 & 1.92 & 1.92 & 1.92 & 1.92 & 1.92 \\
\hline TEC & GWh & 11.36 & 11.83 & 12.30 & 12.77 & 13.24 & 13.72 & 14.19 \\
\hline ECS & $\%$ & 0.00 & 4.16 & 8.31 & 12.47 & 16.63 & 20.78 & 24.94 \\
\hline ECB & $\%$ & 6.80 & 7.08 & 7.37 & 7.65 & 7.93 & 8.21 & 8.50 \\
\hline
\end{tabular}

Where: IAC increase in the amount of sugarcane produced by rainfed sugarcane in Brazil (\%), PRS production of rainfed sugarcane (million t), QBP biomass produced (million t), ERA energy from the rainfed area (GWh), EIA energy corresponding to the irrigated area in Brazil (GWh), TEC total energy cogenerated in Brazil (GWh), ECS increased energy cogenerated in the sector (\%) and ECB energy cogenerated in Brazil (\%).

Currently, in Brazil, from the total cogenerated energy related to the burning of sugarcane bagasse (11.36 GWh), we have 9.44 GWh cogenerated. This number is represented by the 8.48 million hectares of the rainfed area. From the 1.72 million hectares of the irrigated area, we have the proportional remainder of 1.92 $\mathrm{GWh}$ cogenerated. The corresponding increase in energy was calculated over the rainfed area since it has the potential to increase yield with an increase in irrigation and a consequent increase in bagasse for energy generation. Despite being an internationally recognized country for being a reference in the use of renewable energy, Brazil has its share of renewables, among the primary sources of energy in its matrix, which have been stagnant for almost two decades (FAZZI et al., 2020).

According to Table 4, for a $15.00 \%$ increase in yield in Brazilian rainfed sugarcane 
plantations, an increase of $12.47 \%$ in cogeneration increase in the sugar-energy sector is implied. Energy from cogeneration in Brazil increases from $6.80 \%$ to $7.65 \%$, that is, $1.41 \mathrm{GWh}$ of increase in cogenerated energy (greater than all solar energy generated in Brazil - 1.30 GWh). The domestic energy supply in Brazil, in the 2018 survey, of products from sugarcane, represented $6.80 \%$ of the total Brazilian energy supply. In comparison, hydraulic energy represents $64.44 \%$. Oliveira et al. 2020 describe that the sugarcane yields are variable and were considered average yield of $70.0 \mathrm{t} \mathrm{ha}^{-1}$ for rainfed sugarcane, and $126.3 \mathrm{t} \mathrm{ha}^{-1}$ for irrigated sugarcane, over the eight years.

Studies point out that there is a great potential for energy production from sugarcane biomass in Brazil. The low utilization of this potential is not due to the lack of available technologies, nor the conditions of production and supply of the various biomass sources available in the country. They are mainly due to the need to improve the efficiency of the process and investments. (TORQUATO et al., 2016).

Hydroelectric plants, in the dry months (July to October), have the lowest reservoir levels. The great advantage of the cogenerated energy from the sugarcane biomass is that the plants, in these dry months, grind more cane, mainly the plants in the south of central Brazil. Thus, when it rains less, the crushing of sugarcane is greater, and the cogeneration resulting from sugarcane bagasse is maximum in Brazil. To achieve the sustainable use of impounded waters, it is necessary to have a partnership between public authorities and civil society to guarantee water security for all (DANTAS, 2020).

Most sugarcane mills are also located in the south center. In the dry months (between July and October), the sugarcane plantations have a high crop coefficient (Kc), that is, high water demand for the crop. Thus, it is difficult to obtain a high yield of this crop without irrigation in this critical period. Hence, the advantage of installing irrigation in the sugarcane plantations, because in this rain scarcity period, the sugarcane is already grown at the harvest end, and the ideal is to get a high yield crop to supply the industry. Pereira et al. (2015) used values of the average yield of sugarcane, with irrigation, of $140 \mathrm{t} \mathrm{ha}^{-1}$, expressive values that contribute a lot to the industries' milling.
Another point to highlight concerning this drought period is that the plants are already moving towards the harvest end, and the harvesting machines are already in need of maintenance. Moreover, the ideal is to have a quality irrigated sugarcane, with a high yield or high value of a ton of sugarcane per hectare (TCH) to increase the machines' performance in a critical period.

Consequently, with the combination of these factors, irrigated sugarcane, high yield will result in a greater supply of raw material (bagasse) for energy generation at a time when hydroelectric energy meets low energy generation values in Brazil. Electricity generation is, economically, the ideal route to use all the bagasse available for a sugar mill with boilers with a capacity greater than or equal to 150 tons of steam per hour (VARSHNEY et al., 2019).

Finally, the concern with the Brazilian energy matrix amid crises related to the availability of existing natural resources for the generation of electricity made the sugarcane bagasse to be valued as a priority alternative source for electricity generation, considering its great offer and its energy potential (SILVA; LIMA, 2020).

\section{Conclusions}

The increase in irrigation in the rainfed areas of Brazilian sugarcane plantations has substantial potential in increasing biomass for energy cogeneration. Considering a $15 \%$ increase in the production of sugarcane plantations in rainfed areas, obtained from the increase in irrigation, it leads to a potential increase of 96.39 million tons of sugarcane and 26.80 million tons of biomass produced. In the energy matrix, the potential impact is $1.42 \mathrm{GWh}$ of cogenerated energy, which corresponds to a $12.47 \%$ increase in cogeneration in the sugar-energy sector and a $0.85 \%$ increase in Brazil's energy matrix contributing for Brazil to meet the commitment made in the Paris agreement.

\section{REFERENCES}

ANA - Agencia Nacional de Aguas. Levantamento da cana-de-açúcar irrigada na região centro-sul do Brasil. 2017. Available in:< http://arquivos.ana.gov.br/institucional/spr/ Lev antamentoCanalrrigada posCE CEDOC SemISBN 2.pdf $>$ accessed on 20 April 2020. 
ANEEL - Agencia Nacional de Energia Elétrica (Brasil) 2018. Available in:< http://www.aneel.gov.br/ > accessed on 20 April 2020.

CONAB - Companhia Nacional de Abastecimento. Perspectivas para a agropecuária, safra 2019/2020; jan/2020. Brasília: Conab, 2020. V. 6 N.3 - terceiro levantamento. Available in: < https://www.conab.gov.br/perspectivas-para-aagropecuaria > accessed on March 17, 2021.

DANTAS, S. P. Dimensionamento E Gestão De Reservatórios: Breve Discussão Acerca Da Experiência Do Estado Do Ceará/Brasil. Revista Verde Grande: Geografia e Interdisciplinaridade, 2 (01), p. $25 \quad$ - 36.2020. https://doi.org/10.46551/rvg2675239520201253 $\underline{6}$.

EPE - Empresa de Pesquisa Energética. Plano de expansão de energia. 2017. Available in: < http://epe.gov.br/pt > accessed on 20 April 2020.

FAZZI, L. R.; SIMÕES, A. F.; ALMEIDA, P. S.; OLIVEIRA, B. D. A Regulação De Biocombustíveis No Brasil E Nos Eua No Contexto Da Mitigação Das Mudanças Climáticas E Do Correlato Acordo De Paris. Revista Gestão \& Sustentabilidade Ambiental, 9, p. 104 - 119. 2020. DOI: 10.19177/rgsa.v9e012020104-119.

MME - Ministério de Minas e Energia. Balanço energético nacional 2017. Brasília: MME. Available in < http://www.mme.gov.br $>$. accessed on 20 April 2020.

OLIVEIRA, J. T.; CUNHA, F. F.; OLIVEIRA, R. A.; SILVA JUNIOR, A. G.; BUFON, V. B. Economic analysis of two sprinkler irrigation systems for sugarcane and soybean crops in Brazil. International Sugar Journal, 122 (1464), p. 844 850. 2020. Available in: < https://internationalsugarjournal.com/paper/eco nomic-analysis-of-two-sprinkler-irrigationsystems-for-sugarcane-and-soybean-crops-inbrazil/ >. accessed on March 17, 2021.

PEREIRA, R. M.; ALVES JÚNIOR, J.; CASAROLI, D.; SALES, D. L.; RODRIGUEZ, W. D. M.; SOUZA, J. M. F. Viabilidade econômica da irrigação de cana-deaçúcar no cerrado brasileiro. Irriga, Botucatu, v. 1 n. 2, p. 149 - 157. 2015. https://doi.org/10.15809/irriga.2015v1n2p149.
SILVA, R. N.; LIMA, F. E. Estudo do impacto do teor de umidade do bagaço de cana-de-açúcar em sistemas de cogeração. Revista Geama, 6 (2), p. 25 - 33. 2020. Available in: < http://www.journals.ufrpe.br/index.php/geama/ article/view/3029 >. accessed on March 17, 2021.

TAVARES, S. D. L.; DO AMARAL, F. C. S. Determinação do teor de fibra de cana-de-açúcar em diferentes biomas visando o processamento de resíduos para a produção de biocombustíveis sólidos e biomassa energética. In Embrapa SolosArtigo em anais de congresso (ALICE). In: Congresso Internacional De Bioenergia, 9. São Paulo. Anais. Paraná: Porths Eventos. 2014. Available <http://www.alice.cnptia.embrapa.br/alice/handl e/doc/996817 >. accessed on March 17, 2021.

TORQUATO, S. A.; DE JESUS, K. R. E.; RAMOS, R. C. Potencial da bioeletricidade no Brasil: uso da biomassa da cana-de-açúcar como energia alternativa e complementar. In Embrapa Meio Ambiente Artigo em anais de congresso (ALICE). In: IBERIAN CONFERENCE ON RURAL STUDIES, 11. Vila Real. Smart and inclusive development in Rural areas: book of proceedings. Vila Real: SPER, p. 78 - 83. 2016. Available in: <http://www.alice.cnptia.embrapa.br/alice/handl e/doc/1065049 >. accessed on March 17, 2021.

UNFCC - Convenção do Quadro das Nações Unidas sobre Mudança do Clima. 2018. Available in < https://unfccc.int/ > accessed on 20 April 2020.

UNICA - União da Indústria da cana-de-açúcar. Linha do tempo da cana-de-açúcar. 2018. Available in:< http://www.unica.com.br/ > accessed on 20 April 2020.

VARSHNEY, D.; MANDADE, P.; SHASTRI, Y. Multiobjective optimization of sugar cane bagasse utilization in an Indian sugar mill. Sustainable Production and Consumption. p. $96-114$, Mumbai, India. 2019. https://doi.org/10.1016/j.spc.2018.11.009. 